\title{
Constraints Faced by the Farmers in Adoption of Improved Cultivation Practices of Gram
}

\author{
V.S. Parmar*, N.S. Joshi, P.J. Prajapati and N.J. Hadiya \\ Krishi Vigyan Kendra, JAU, Amreli, India \\ *Corresponding author
}

\begin{tabular}{|l|}
\hline Key w or d s \\
$\begin{array}{l}\text { Gram, KVK, Ex- } \\
\text { post-facto }\end{array}$ \\
\hline Article Info \\
\hline $\begin{array}{l}\text { Accepted: } \\
\text { 17 October } 2019 \\
\text { Available Online: } \\
10 \text { November } 2019\end{array}$ \\
\hline
\end{tabular}

A B S T R A C T
Amreli district has good scope for agricultural development due to various agro-ecological regions. This study was undertaken in Krishi Vigyan Kendra, Amreli (Guj.) during the period 2018-19. Various trainings, FLDs and lectures are conducted by scientists of KVK to improve the cultivation practices of gram in Amreli district. This study emphasis on constraints faced by farmers to adopt an improved cultivation practices in gram. Expost-facto research design was used in the present investigation. Total 90 respondents selected for the study. Final results revealed that major constraints perceived by respondents were, unavailability of vermicompost as per recommendation and ranked at first position followed by lack of knowledge about plant based botanical insecticides and pesticides, unavailability of farm yard manure, non-availability of fertilizers in time, no information about seed treatment and lack of knowledge about bio fertilizers.

\section{Introduction}

Gram is one of the important pulse crops in Amreli district of Saurashtra region. Gram has great importance in human diet due to its content protein. Among the pulse crop, Gram is an important and unique food legume because the variety of food products like snake food, sweets, condiments and vegetables are prepared from it worldwide.
Amreli is agriculture dominated district. About $80 \%$ of population is engaged in agriculture and allied activities. Amreli district offers good scope for agricultural development. Agricultural production potential depends mostly on the management practices.

These practices vary significantly across various agro-ecological regions due to many 
factors. It showed improvement in gram production is needed through conservation, diversification of agriculture and to enhance adoption level of improved gram production technology.

So to increase the productivity, particularly under rainfed, gram growing regions is one of the major challenges and concern which need to be addressed on priority basis. Variety of seed is one of the important factors for increasing productivity among the other yield attributing inputs available in gram cultivation.

The genetic potential of grain yield of gram is still under estimated as a result of strong and dominating effects of economy. The fact is that the ultimate aim of gram growers is to get higher remunerative income through use of superior varieties existing once in yielding ability, disease and insect resistance and other characteristics.

But many hurdles for successfully adoption of improved cultivation practices of gram in Amreli district are faced. Gram crop is suffering from various insect, pest, disease, weed and nutrient deficiency among them the pest attack create more losses throughout their production and farmers uses various pesticide for production of gram.

Keeping this fact in view, it is necessary to study constraints in adoption of improved cultivation practices of gram in Amreli district, with following specific objectives.

\section{Objectives}

To study constraints faced by respondents in adoption of improved cultivation practices of gram.

To study the suggestions given by respondents to overcome the constraints.

\section{Materials and Methods}

Present study was conducted in Amreli district of Saurashtra region. Three talukas named Dhari, Amreli and Babra where maximum number of FLDs given in previous years, purposively selected and from each taluka three villages selected randomly. Total nine villages from selected talukas constitute the total sample size 90 means each village 10 farmers selected for study (Table 1).

Ex-post-facto research design was used in the present investigation. The interview schedule was developed keeping in view the specific objectives of the study and the data was collected by survey method during year 201819.

Constraints refer as the difficulties as perceived by the respondents to adopt improved practice of gram. Percentage was worked out for each of the constraints and overall ranks were assigned on the basis of percentage. Based on the constraints perceived by the respondents to adopt improved practice of gram, possible suggestions were seeked from them. Percentage was work out for each suggestion and overall ranks were assigned on the basis of percentage.

\section{Results and Discussion}

\section{Constraints faced by the farmer's adoption of improved cultivation practices of gram}

Constraints in adoption of new technology never end. However they can be minimized. The respondents were requested to express the constraints faced by them in adoption of improved cultivation practices of gram.

The data presented in table 2 found that major constraints perceived by respondents were, Unavailability of vermicompost as per recommendation; 86.67 per cent and ranked at 
first position followed by Lack of knowledge about plant based botanical insecticides and pesticides; 85.56 per cent, Unavailability of farm yard manure; 82.22 per cent, Nonavailability of fertilizers in time; 70.00 per cent, No information about seed treatment; 64.44 per cent, Lack of knowledge about bio fertilizer; 50.00 per cent, Lack of guidance about recommended technology; 48.89 per cent, Non availability of NPV in market; 46.67 per cent, Non availability of improved seed; 43.33 per cent which ranked at II, III, IV, V, VI, VII, VIII and IX respectively.

\section{Suggestions from the farmers to overcome the constraints}

An attempt was also made to ascertain suggestions from farmers to overcome various constraints faced by them in adoption of improved cultivation practices of gram. The respondents were requested to offer their valuable suggestion against difficulties faced by them in the adoption of improved cultivation practices of gram. The data were collected and summarized in table 3 . The data presented in table 3 revealed that major suggestions given by respondents were, Availability of all input through cooperatives; 90.00 per cent and ranked at first position followed by Providing seeds, pesticides and fertilizers at reasonable rate; 83.33 per cent, Knowledge about seed treatment methods should be provided; 81.11 per cent, Assured availability of bio fertilizer and bio pesticide; 65.56 per cent, Timely availability of improved seed; 57.78 per cent, Provision of training in regards about plant based botanical insecticides and pesticides; 54.44 per cent which ranked at II, III, IV, V and VI respectively.

It can be concluded from the above study that, major constraints perceived by respondents were, Unavailability of vermin-compost as per recommendation, Lack of knowledge about plant based botanical insecticides and pesticides and Unavailability of farm yard manure. Major suggestions given by respondents were, Availability of all input through co- operatives, Providing seeds, pesticides and fertilizers at reasonable rate and Knowledge about seed treatment methods should be provided.

Table.1 List of villages selected for the study

\begin{tabular}{|c|c|c|c|}
\hline Sr. No. & Name of Taluka & Name of Village & No. of respondents \\
\hline \multirow[t]{3}{*}{1.} & \multirow[t]{3}{*}{ Amreli } & Haripura & 10 \\
\hline & & Keriya nagas & 10 \\
\hline & & Babapur & 10 \\
\hline \multirow[t]{3}{*}{2.} & \multirow[t]{3}{*}{ Dhari } & Dittla & 10 \\
\hline & & Sarasiya & 10 \\
\hline & & Gigasan & 10 \\
\hline \multirow[t]{3}{*}{3.} & \multirow[t]{3}{*}{ Bagasara } & Halariya & 10 \\
\hline & & Vaghaniya Juna & 10 \\
\hline & & Rafala & 10 \\
\hline \multicolumn{3}{|c|}{ Total } & 90 \\
\hline
\end{tabular}


Table. 2 Constraints faced by the respondents' adoption of improved cultivation practices of gram

\begin{tabular}{|r|c|c|c|c|}
\hline Sr. & Constraints & F & Percentage & Rank \\
No. & Lack of knowledge about bio fertilizer & 45 & 50.00 & VI \\
\hline $\mathbf{1}$ & Non availability of improved seed & 39 & 43.33 & IX \\
\hline $\mathbf{2}$ & $\begin{array}{c}\text { knowledge about Plant based botanical } \\
\text { Insecticides and Pesticides }\end{array}$ & 77 & 85.56 & II \\
\hline $\mathbf{3}$ & Lack of & 63 & 70.00 & IV \\
\hline $\mathbf{4}$ & Non availability of fertilizers in time & 42 & 46.67 & VIII \\
\hline $\mathbf{5}$ & Non availability of NPV in market & 78 & 86.67 & I \\
\hline $\mathbf{6}$ & Unavailability of vermicompost as per & & & \\
\hline $\mathbf{7}$ & recommendation & 74 & 82.22 & III \\
\hline $\mathbf{8}$ & Unavailability of farm yard manure & 58 & 64.44 & V \\
\hline $\mathbf{9}$ & No information about seed treatment & 44 & 48.89 & VII \\
\hline
\end{tabular}

Table.3 Suggestions from the respondents to overcome the constraints

\begin{tabular}{|c|c|c|c|c|}
\hline Sr. & Suggestion & F & Percentage & Rank \\
No. & Timely availability of improved seed & 52 & 57.78 & V \\
\hline $\mathbf{1}$ & Availability of all input through co- operatives & 81 & 90.00 & I \\
\hline $\mathbf{2}$ & Assured availability of bio fertilizer and bio pesticide & 59 & 65.56 & IV \\
\hline $\mathbf{3}$ & $\begin{array}{c}\text { Provision of training in regards about Plant based } \\
\text { botanical Insecticides and Pesticides }\end{array}$ & 49 & 54.44 & VI \\
\hline $\mathbf{4}$ & & & \\
\hline $\mathbf{5}$ & Knowledge about seed treatment methods should provided & 73 & 81.11 & III \\
\hline $\mathbf{6}$ & $\begin{array}{c}\text { Providing seeds, pesticides and fertilizers at reasonable } \\
\text { rate }\end{array}$ & 75 & 83.33 & II \\
\hline
\end{tabular}

\section{References}

Chandawat, M. S., Sharma, P. K., and Parmar, A. B. (2012). Extent of adoption about improved cultivation practices of gram crop and constraints faced by the farmers of Kheda district. Guj. J Extn. $E d u$, 23: 26-29.

Sharma, B. L. and Sharma, R. N. (2007). Adoption and impact of recommended technology of kharif pulse crops in Agro-climatic zone II-A of Rajasthan. Raj. J Extn. Edu., 15: 122-128.

Thoke N. and Gunjal S. (2009). Constraints and suggestions of Chickpea growers in adoption of its production technology. Agril. Update, 4 (3\&4): 411-413.

Thombre, A. P., Ghulghule, J. N. and More, S. S. (2009). Economics of production of black gram in Marathwada region of Maharasthra state. Agril. Update, 4 (12): $167-171$.

Thombre, A. P., Ghulghule, J. N. and More, S. S. (2009). Constraints faced by pulse grower in production and marketing and suggestion made by them in Economics of production of black gram in Marathwada region of 
Maharasthra state. Agril. Update, 4 (12): $173-175$.

Thorat, K. S. (2012). Technological gap in adoption of recommended cultivation practices of mango growers and constraints faced by them. Mysore Journal of Agricultural Sciences, 46 (1) : 160-163.

Patel H. B., Bhatt, P. M. and Soni, N. V. (2011). Constraints Faced by the banana growers in adoption of improved banana cultivation practices. Guj. J. Ext. Edu., 22: 92-95.

Jatapara, A. C., Soni, N. V. and Vyas, B. H.
(2017). Constraints faced by the gram growers in adoption of improved cultivation practices of gram crop. $G u j$. J. Ext. Edu., 28(1): 52-54.

Dupare B. W., Billore S. D., Joshi O. P. and Verma, S. K. (2011). Adoption of improved soybean technology in Madhya Pradesh: A critique. $J$. Oilseeds Res., 28(2): 125-130.

Markana, J. G., Kalsariya, B. N. and Bharad, N. D. (2015). Constraints faced by farmers in adoption of scientific kharif groundnut production technologies. Guj. J. Ext. Edu., 26(1): 43-46.

\section{How to cite this article:}

Parmar, V.S., N.S. Joshi, P.J. Prajapati and Hadiya, N.J. 2019. Constraints Faced by the Farmers in Adoption of Improved Cultivation Practices of Gram. Int.J.Curr.Microbiol.App.Sci. 8(11): 2071-2075. doi: https://doi.org/10.20546/ijcmas.2019.811.239 